\title{
Reimagining large-scale open-water fisheries governance through adaptive comanagement in hilsa shad sanctuaries
}

\author{
Martin L. van Brakel $^{1}, \underline{\text { Md. Nahiduzzaman }}^{1}, \underline{\text { A. B. M. Mahfuzul Haque }}{ }^{1}, \underline{\text { Md. Golam Mustafa }}^{1}, \underline{\text { Md. Jalilur Rahman }}{ }^{1}$ and $\underline{\text { Md. Abdul }}$ \\ $\underline{\text { Wahab }}^{1}$
}

\begin{abstract}
Almost a half million fishers in Bangladesh are predominantly reliant on the hilsa shad (Tenualosa ilisha) fishery in the Meghna River and estuarine ecosystem. This paper adopts a broadened concept of social-ecological traps to frame the complex dynamics that emerge from social and ecological interactions in this highly natural resource-dependent social-ecological system (SES). We analyze how endogenous self-reinforcing processes in the system and poor initial conditions, particularly debt and lack of livelihood options outside fisheries, keep fishing households in poverty. We identify a policy decision in favor of incentive-based fisheries management as a critical juncture that influenced a trajectory of recovery in hilsa shad stocks in this complex adaptive system. Normative assessment of stakeholder perceptions indicates that fishers perceive a nominal improvement in well-being as a result of this policy. Compensation in return for compliance with a seasonal fishing ban in sanctuary areas does not, however, disrupt trap dynamics perpetuating the cycle of poverty, social exclusion, and political disempowerment in which fishing households are entrenched. Poverty and lack of alternative livelihood opportunities remain significant reasons for noncompliance with the ban as long as fishers do not have any meaningful representation in resource management and decision making. A secured tenure system through adaptive comanagement involving fishers in monitoring and enforcement of compliance with fishing bans, supported by sustainable finance for livelihood improvements outside of natural resource exploitation and predicated on responsive and accountable institutions for and by people who depend on the fishery, can form the foundation for local stewardship in a unique demonstration of contemporary largescale open-water fisheries governance in this complex SES.
\end{abstract}

Key Words: Bangladesh; comanagement; debt; hilsa shad; sanctuary; social-ecological system; trap

\section{INTRODUCTION}

Numerous studies have shown that poverty arises from complex interactions between social and environmental factors (e.g., Reardon and Vosti 1995, Barbier 2010, Nunan 2015, and references therein). Those studies often capture the complex relationship between poverty and environment in the concept of a poverty trap (e.g., Barrett and Swallow 2006, Barbier 2010, Stoop et al. 2016). Barbier (2010: 647) presents a trap model that challenges the "perception of a 'poverty-environment trap' as a two-way process in which poverty drives rural households to degrade the environment, and a deteriorating environment subsequently worsens poverty," arguing instead that such traps encompass more complex relationships between asset poverty, lack of income opportunities or access to markets for land, labor, and credit, and the availability and quality of natural resources, including land. The development economics literature, where the concept originates, conceptualizes a poverty trap as a persistent, self-reinforcing state under a well-being threshold that needs to be overcome through increased inputs or institutional changes. Barrett and Swallow (2006) theorize a poverty trap that is selfreinforcing through feedback effects, in which multiple dynamic equilibria exist simultaneously at multiple scales of analysis. The social-ecological literature conceptualizes poverty traps as unsustainable situations that are reinforced through feedbacks between social and ecological processes, and suggests interventions that undo trap dynamics by breaking dominant reinforcing feedbacks that maintain the trap (Haider et al. 2018). Boonstra and de Boer (2014) conceptualize social-ecological traps as path-dependent processes and outline how path dependency can be used for the analysis of social-ecological traps. They identify critical junctures to avoid and move out of traps. Haider et al. (2018) broaden the concept of poverty traps to account for cross-scale and social-ecological dynamics. They propose an integrated social-ecological concept of traps that includes considerations of cross-scale interactions, path dependencies, the role of external drivers, and social-ecological diversity to better account for the diverse feedbacks that produce and maintain poverty traps.

Temporal and scale mismatches underlie social dilemmas of collective action, such as the "tragedy of the commons" where exploiting a shared resource at the individually optimal level conflicts with collective benefits and long-term sustainable use (Boonstra and de Boer 2014). Overfishing, commonly explained through Hardin's (1968) classical metaphor where the "tragedy" refers to instances when people fail to solve dilemmas of collective action, is increasingly conceptualized as a linked social-ecological process with critical feedbacks that can drive a system toward less desirable configurations. Recontextualizing overfishing as such may help confront the problem and find creative solutions to break the social-ecological feedback loops that perpetuate the cycle of poverty and natural resource degradation (Cinner 2011). We frame contemporary management of the hilsa shad (Tenualosa ilisha) fishery in the Meghna River and estuarine ecosystem, a vast tidal delta waterscape that stretches over 350 $\mathrm{km}$ of rivers in southern Bangladesh (Fig. 1), within a socialecological system (SES) perspective. We analyze drivers of trap dynamics within this system with the objective of identifying management interventions that can steer the fishery toward a trajectory of sustained development. The considerations identified by Haider et al. (2018) do, in our perspective, account for the complex dynamics that emerge from social and ecological interactions in this complex, highly natural resource-dependent 
SES. We therefore adopt the broadened concept of socialecological traps proposed by Haider et al. (2018) as framework for reimagining large-scale open-water fisheries governance of the Meghna River linked SES in southern Bangladesh.

Fig. 1. Map of the study area covering the Meghna River and estuarine ecosystem, southern Bangladesh, with locations of surveyed hilsa fishing villages within sanctuaries and outside sanctuaries

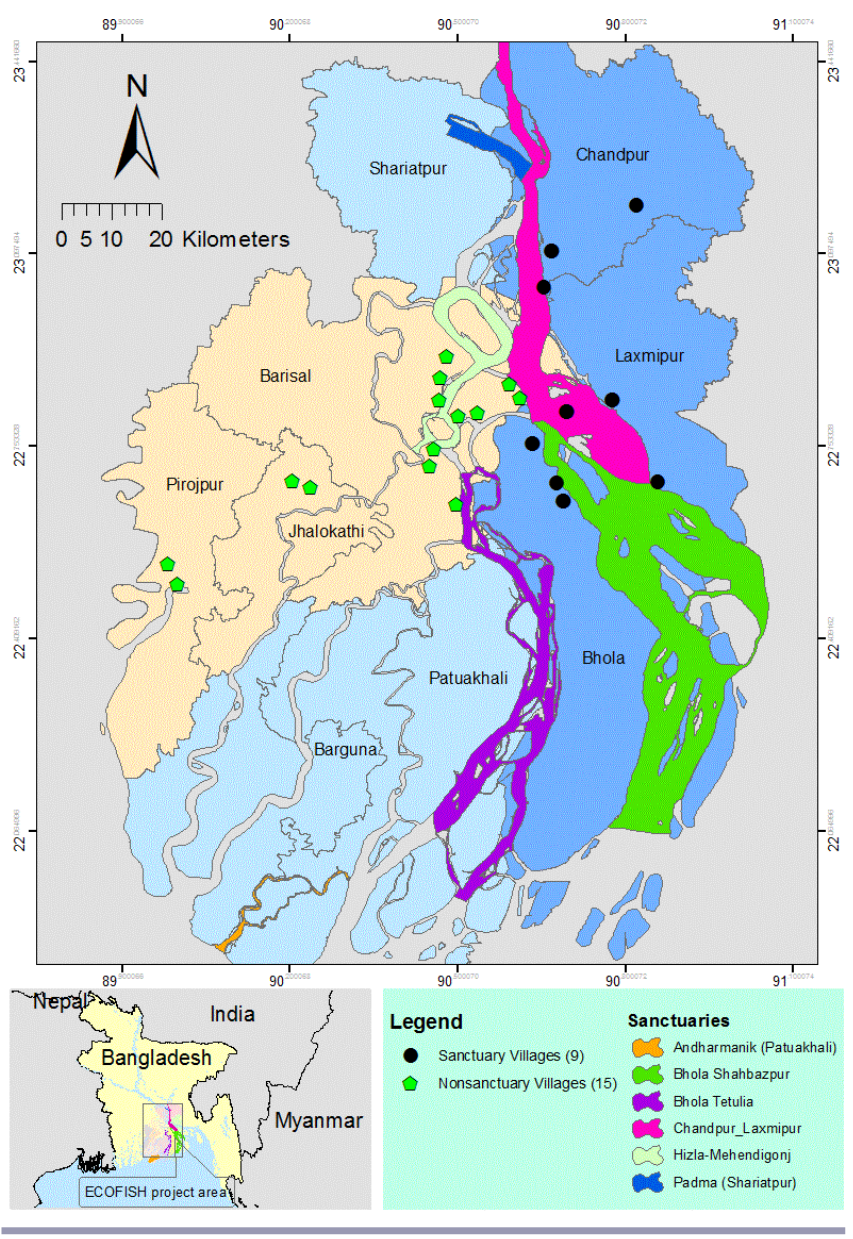

\section{METHODOLOGY}

First, we analyze external factors affecting trap dynamics in the Meghna River linked SES. We briefly analyze the status and trends of the hilsa fishery in Bangladesh to identify how historical dynamics and critical junctures have influenced trap dynamics. We explicitly give consideration to path dependency in our analysis. We examine how external drivers affect trap dynamics and livelihoods of more than 15,000 households predominantly relying on the hilsa shad fishery in the Meghna River and estuarine ecosystem. Our normative assessment of stakeholder perceptions of five hilsa fish sanctuaries and their impacts, drawn from a crosssection of 1,200 fishing households in 24 villages reliant on this system, generates a better understanding of (i) awareness of and compliance with fishing bans in these sanctuaries and (ii) perceptions of benefits received in return for compliance. We review recent literature describing and discussing stakeholders' perceptions of the incentive-based approach to hilsa fisheries management adopted by the government of Bangladesh and compare and contrast those perceptions with our own findings.

Second, we analyze endogenous self-reinforcing processes in the system and poor initial conditions that keep these households in poverty, such as low asset ownership and debt, to analyze how reliance on this SES affects their livelihoods. We compare stakeholder perceptions and socioeconomic profiles of hilsa fishing households within sanctuary areas to those outside sanctuary areas. From our perspective, we consider households who live in communities in close proximity, i.e., adjacent to sanctuaries as living "within" sanctuaries because their livelihood depends primarily on fishing within them. Our survey uses a quantitative methodology based on a questionnaire that captures three key sets of variables of interest: household shock exposure, household well-being outcomes, and household and community capacities that promote resilience. The survey covers a sample of 450 hilsa fishing households who live within sanctuary areas in Bhola, Chandpur, and Laxmipur districts, and 750 households who live outside sanctuary areas, in Barisal, Jhalokati, and Pirojpur (Fig. 1). The sample was drawn by two-stage stratified cluster sampling from a sample frame generated by a separate household listing exercise. At the first stage, clusters were divided into sanctuary and nonsanctuary areas. At the second stage, the 24 sample villages were selected independently from six strata encompassing the districts within those areas, with probability proportional to the population in each stratum. Fifty households were interviewed in each village. A pool of 30 data enumerators were involved in the data collection process, using mobile devices (Google Nexus) with an electronic questionnaire based on Open Data Kit (ODK) software. All records were stored and uploaded to a cloud server using the built-in internet connectivity of the devices.

Finally, we reimagine large-scale open-water fisheries governance of the Meghna River linked SES. We discuss limitations and opportunities arising from two contrasting "plausible scenarios" or future trajectories to escape the social-ecological trap, and engage in grounded speculation about how local stewardship of the system and its resources, through adaptive comanagement coupled with sustainable finance for livelihood improvement, can offer pathways to help fishing households escape the socialecological trap.

\section{STATUS AND TRENDS OF THE HILSA FISHERY IN BANGLADESH}

The hilsa shad fishery is the largest and most valuable single species fishery in Bangladesh. Hilsa contributes about $10.5 \%$ of the country's total fish production and $1.0 \%$ to the gross domestic product (Fisheries Resources Survey System (FRSS) 2017). Mome (2007) evaluates an average hilsa production of about 215 thousand tons at USD $\$ 380$ million per year, but at current yields and market prices, estimated by Sahoo et al. (2016) to be on average around USD \$12 per kg, the actual market value may be at least ten times higher. Moreover, we note that Mohammed et al. (2016) estimate the fishery's nonconsumptive value to be in the order of USD \$167.5 million to USD \$355.7 million per year. The hilsa shad fishery is a predominantly artisanal gillnet fishery that provides a livelihood to almost a half million full-time fishers, who are heavily reliant on this fishery and have limited alternative 
Table 1. Critical junctures and endogenous processes (social and ecological) that have influenced trap dynamics, perception, and capacity-based attributes of each SES configuration, and its financial implications

\begin{tabular}{|c|c|c|c|c|c|}
\hline \multirow[t]{2}{*}{$\overline{\text { Critical junctures (past) }^{\dagger}}$} & \multicolumn{2}{|c|}{ Endogenous processes and trap dynamics ${ }^{\dagger}$} & \multicolumn{2}{|c|}{ Attributes of SES configuration } & \multirow[t]{2}{*}{ Financial implications } \\
\hline & Social & Ecological & Attitude and perception & Capacity and entitlement & \\
\hline $\begin{array}{l}\text { (1) Open access to river } \\
\text { fisheries (September 1995) }\end{array}$ & $\begin{array}{l}\text { Poverty and resource } \\
\text { competition reinforce } \\
(+) \text { trap dynamics }\end{array}$ & $\begin{array}{l}\text { Overfishing and } \\
\text { environmental } \\
\text { degradation } \\
\text { reinforce (+) trap } \\
\text { dynamics }\end{array}$ & $\begin{array}{l}\text { Temporal and scale } \\
\text { mismatch underlie social } \\
\text { dilemmas of collective } \\
\text { action, and reinforce } \\
\text { overfishing }\end{array}$ & $\begin{array}{l}\text { High reliance on fishery } \\
\text { but no tenure entitlement; } \\
\text { few alternative options }\end{array}$ & $\begin{array}{l}\text { Reduced economic } \\
\text { value of fishery; } \\
\text { poverty and reduced } \\
\text { income for ca. } 3 \\
\text { million resource users }\end{array}$ \\
\hline $\begin{array}{l}\text { (2) HFMAP (2003-2004) } \\
\text { and "carrot-and-stick" } \\
\text { management in sanctuaries } \\
\text { in response to declining } \\
\text { stocks }\end{array}$ & $\begin{array}{l}\text { Compensation in } \\
\text { return for compliance, } \\
\text { but poverty and debt } \\
\text { lock-in maintain }(+) \\
\text { trap dynamics }\end{array}$ & $\begin{array}{l}\text { Recovery of hilsa } \\
\text { stocks and } \\
\text { biodiversity alter (-) } \\
\text { trap dynamics }\end{array}$ & $\begin{array}{l}\text { High awareness of } \\
\text { regulations but low } \\
\text { perceived benefits of } \\
\text { compensation and stock } \\
\text { recovery incentivize } \\
\text { noncompliance } \\
\text { Ban perceived as major } \\
\text { and recurrent shock to } \\
\text { livelihood }\end{array}$ & $\begin{array}{l}\text { High reliance on fishery; } \\
\text { entitlement to } \\
\text { compensation but not to } \\
\text { tenure } \\
\text { Low capacity for } \\
\text { alternative income } \\
\text { generation }\end{array}$ & $\begin{array}{l}\text { Economic value of } \\
\text { fishery at least double } \\
\text { to } 10 \text {-fold from USD } \\
\$ 380 \text { million per year; } \\
\text { incentive package } \\
\text { costs ca. USD } \$ 14 \\
\text { million per year }\end{array}$ \\
\hline
\end{tabular}

See Fig. 2

livelihood options. Dewhurst-Richman et al. (2016) estimate that another 2.5 million people are engaged parttime in the hilsa fishery and ancillary activities.

Hilsa was once abundant in Bangladesh and the fish has historical significance in Bengali culture. The old custom that Bengalis should purchase a pair of hilsa on the day of "Vijay Dashami," observed on the full moon day in the Hindu calendar month of "Ashwin," typically falling in October, and after that, not eat it again until the Hindu spring festival "Vasant Panchami" observed on the fifth day of "Magh" (typically February), for example, has a scientific basis because the major hilsa breeding season falls within this period (Sharma et al. 2012). Unfortunately, such customary beliefs and values reflecting conservation measures that have been practiced traditionally over the centuries are deteriorating, as are traditional tenure systems such as the "Pata" hereditary system that maintains socially organized, locally enforceable, and hereditary entitlements as a way to avoid conflict among fishers regarding access and use of fishing space (Jentoft et al. 2010). From the 1970s onward, population growth has fuelled the overexploitation of coastal fisheries. Heavy exploitation and indiscriminate harvesting of brood stocks and juveniles, locally known as "jatka," has led to a gradual decline in yields of hilsa in inland waters. The total hilsa yield, however, remained stable at about $200,000 \mathrm{t}$ per year due to an increase in yield from the marine sector (Amin et al. 2008).

\section{Critical junctures influencing trap dynamics in the Meghna River linked social-ecological system}

Past and present government fisheries policies in Bangladesh have, perhaps unintentionally, discouraged local institutions for fisheries protection and sustainable management. Public water bodies known as "jalmohals" are leased to the highest bidder in order to generate revenue, often bringing them under the control of rich and influential lessees. Fishers suffer from declining catches and have failed to gain fishing rights under this leasing system (Thompson et al. 1999). In September 1995, political pressure prompted the government to end competitive leasing of flowing waters, and fishing in rivers became de facto open access
(Pomeroy et al. 2016). We identify this policy change toward open access as the first critical juncture, creating an abrupt "deinstitutionalization" in open-water fisheries governance. An open-access regime retains the competition between fishers. Under a resource-constrained open-access configuration, competition becomes an endogenous self-reinforcing process that keeps fishers in poverty (Table 1; Fig. 2). Under these conditions, no formal basis exists for establishing territorial use rights over open-water fish resources (Thompson et al. 1999), limiting the potential for decentralized comanagement. As a consequence, fishers in the Meghna River and estuarine ecosystem, where most hilsa is caught, do not have secure rights over the fishery resources they are predominantly reliant upon. If small-scale fishers and coastal communities were to exercise such rights, they would have a strong interest in organizing and acting collectively to manage their resources sustainably (Pomeroy et al. 2016).

The second critical juncture (Table 1; Fig. 2) came when hilsa yield levels declined to below 200,000 t during 2003-2004 (FRSS 2017), which prompted the government of Bangladesh to launch the Hilsa Fisheries Management Action Plan (HFMAP) with the aim of protecting jatka and brood hilsa. The government declared five zones that are known to be important hilsa spawning and nursery grounds in the country's coastal rivers as sanctuaries in an attempt to reverse the decline (Mohammed and Wahab 2013). Moreover, each year from November to June, a complete ban on jatka catch is being enforced under the 1950 Protection and Conservation of Fish Act. A positive impact in terms of survival of brood hilsa and increased production of hatchlings and juveniles has been attributed to these management interventions. Since they were introduced, yields have increased considerably, according to official landing estimates reaching 395,000 t in 2015-2016, of which the share from the marine sector was $65 \%$ (FRSS 2017). It is also believed that the management interventions have contributed to the maintenance of biodiversity of other fishes in the sanctuaries and adjacent areas of the rivers. Notwithstanding the apparent recovery of hilsa stocks witnessed since the interventions took effect, poverty and indebtedness continue to 
be major drivers of noncompliance with the existing fishery laws and regulations (Islam et al. 2017). The combination of dwindling hilsa yields and harvest restrictions, introduced by the government of Bangladesh in response to the witnessed decline, have created hardship for communities and households whose livelihood depends on this natural resource.

Fig. 2. A conceptual model of critical junctures in the past, leading toward SES configurations of (1) open access; (2) incentive-based approach, and potential future junctures leading toward (3) blanket ban; (4) comanagement. Social and ecological feedbacks (dashed lines and arrows) in the corresponding SES configurations reinforce (+) or alter (-) and ultimately may disrupt trap dynamics. Gray arrows pointing into the configurations are key endogenous drivers of trap dynamics in each configuration

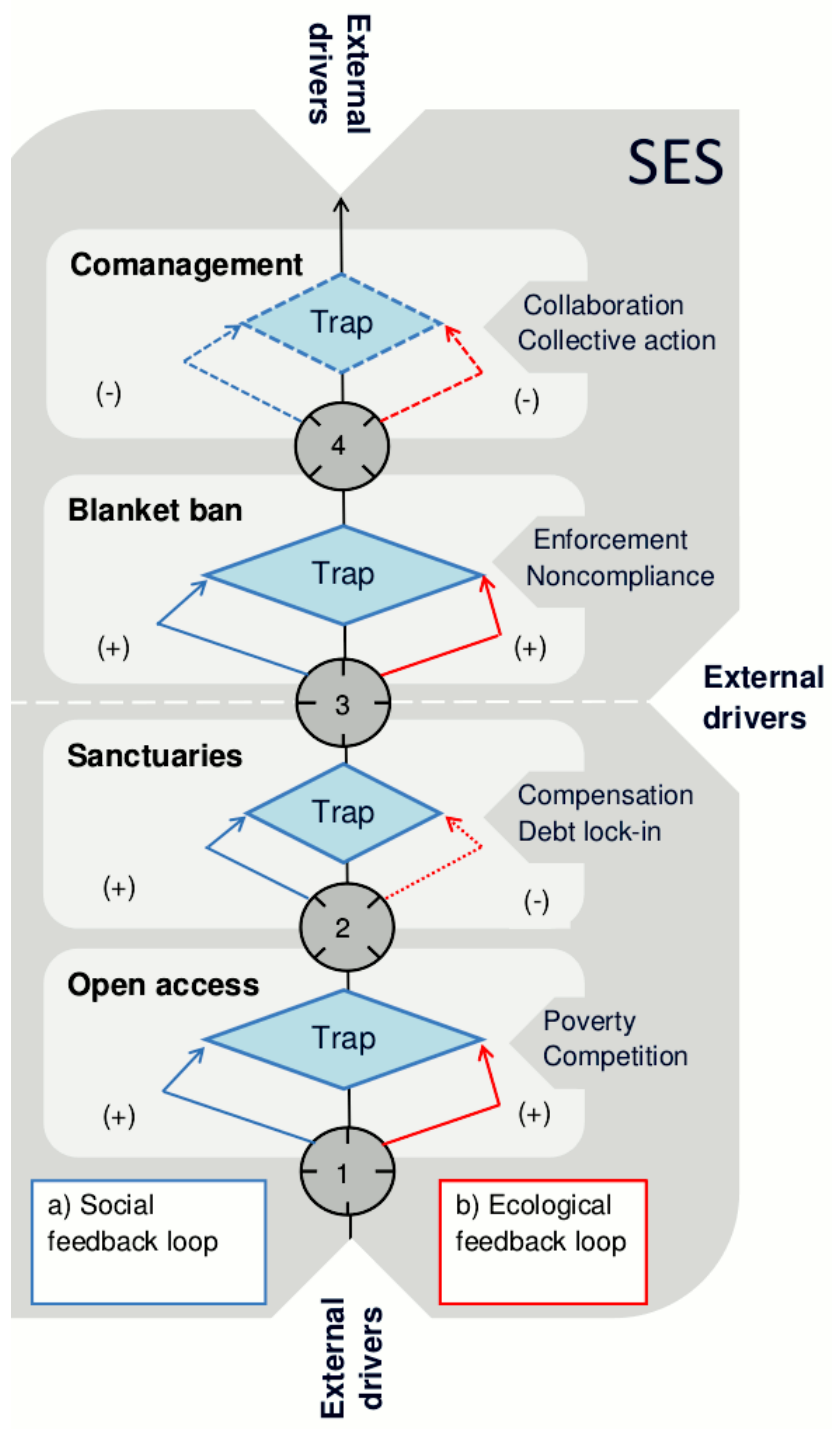

\section{An incentive-based approach to fisheries management in} Bangladesh

Since the adoption of the HFMAP, management of Bangladesh's hilsa shad fishery has moved from a strict regulatory regime to an approach that combines regulations with direct economic incentives in a "carrot-and-stick" approach that compensates fishing households affected by seasonal hilsa fishing bans (Mohammed and Wahab 2013). This incentive-based hilsa conservation program is unprecedented in its scale and has been hailed as "a rare example of the use of direct economic incentives for sustainable fisheries in a developing country context" (Mohammed and Wahab 2013) and "the most cost-effective and efficient way to manage natural resources" (Haldar and Ali 2014). Fully funded by the government of Bangladesh through a preexisting Vulnerable Group Feeding (VGF) program, it currently provides more than 200,000 affected households with $40 \mathrm{~kg}$ of rice per month, from February to May each year. Haldar and Ali (2014) calculate the total cost incurred once a year for ca. $36,000 \mathrm{t}$ of food grain allocation and distribution at around BDT 1.22 billion (ca. USD $\$ 14$ million at 2017 exchange rates), of which administration costs are BDT 10.9 million, equivalent to a market value of about $250,000 \mathrm{~kg}$ of rice. Moreover, some 22,000 households living in sanctuary areas have received training and support for alternative income-generating activities valued at almost BDT 164 million (USD \$2 million) in compensation for the loss of earnings due to fishing restrictions. The approach could set the stage for a unique demonstration of contemporary largescale open-water fisheries governance, but has not yet been accompanied by devolution of power from the central state to resource users, nor has it been predicated on responsive and accountable institutions for and by people who depend on the fishery.

The Enhanced Coastal Fisheries in Bangladesh (ECOFISHBangladesh) project, a joint initiative of the Bangladesh Department of Fisheries (DoF) and WorldFish, has initiated the establishment of ecosystem-scaled comanagement institutions that aim to support a cooperative and integrated system of governance in the five designated hilsa fish sanctuaries with the objectives of conserving the resource and improving resilience of the Meghna river and estuarine ecosystem as a whole, including its communities reliant on coastal fisheries. One of the prerequisites, clarity and security of tenure, implies that communities of small-scale fishers must have some entitlement of ownership or control over the system if they are to be held accountable for ecosystem service delivery. Meeting this prerequisite is particularly challenging in the context of the hilsa fishery given the high mobility of this migratory fish and the large number of fishers relying on open-water fishery in the Meghna River and estuarine ecosystem, which in terms of total production supports the largest estuarine fishery in the world (Blaber 2000, cited in Islam et al. 2017).

\section{RESULTS}

External factors affecting trap dynamics in the Meghna River linked social-ecological system

Classical top-down external interventions such as policy reform may maintain, reinforce, or alter trap dynamics. Earlier in this paper, we identified the adoption of the HFMAP, culminating in the declaration of the five hilsa fish sanctuaries, as a critical 
juncture in the trajectory of the Meghna River linked SES. In this section, we present a normative assessment of stakeholder perceptions of sanctuaries and their impacts. We deliberate how this policy intervention, which may be regarded as the principal exogenous social-ecological driver affecting trap dynamics in the Meghna River linked SES, is being perceived to affect the livelihoods of stakeholders reliant on this system. We consider local knowledge and perceptions of "carrot-and-stick" hilsa fishery management among households within sanctuary areas and households outside sanctuary areas from two angles: (i) awareness of regulations and attitudes toward compliance (the "stick"), and (ii) perceptions of benefits (the "carrot") provided by the government in return for compliance with the fishing ban. Perhaps the most noteworthy outcome of the survey in this context is that respondents almost unanimously identify the two months' ban enforced on all fisheries within sanctuaries during March and April each year as the most severe shock affecting their livelihood. This indicates that awareness about the ban period is high, but benefits in return for compliance are perceived to be low. We add one caveat here: the finding that more than $99 \%$ of respondents outside sanctuary areas also perceive the ban on fisheries within sanctuaries as a major shock to their livelihood seems counterintuitive and cannot be conclusively explained. One possible explanation is that fishers outside sanctuaries "follow the fish" and perceive forgone benefits from not being able to fish within sanctuaries during the ban period.

The studies that we review also raise concerns about adverse socioeconomic implications of ban periods on fishing livelihoods. Despite the perceived socioeconomic and ecological benefits associated with compensation, the effectiveness of this modified top-down management approach in terms of improved "voluntary" compliance with fishing bans remains questionable, and its implementation is fraught with problems. Islam et al. (2016a) report that $65 \%$ of respondents depending on fishing in hilsa sanctuary areas are of the opinion that the sanctuaries adversely impact their ability to meet their household food consumption needs. Respondents complain that the added harvest is much less than their lost income. The negative consequences of sanctuaries on the socioeconomic status of fishers could ultimately lead to unintended ecological consequences through social noncompliance (Isaacs 2011 and Mascia et al. 2010, cited in Islam et al. 2016a). Despite the appreciation of the management and conservation initiatives aimed at protecting the hilsa fishery expressed by the majority of respondents in their study, Islam et al. (2016a:314-315) conclude: "In fact, the loss of rights to fish in sanctuaries has resulted in increased poverty, indebtedness, non-compliance and hence, criminalization among fishers."

(i) Awareness and compliance

Our survey reveals that fishermen are well aware of the jatka and brood hilsa fishing ban period. Eighty-three percent of respondents indicate that they are aware of the fishing ban through government publicity campaigns. Most respondents are of the opinion that general awareness through such campaigns contributes most importantly to effective implementation of the fishing ban. More than $90 \%$ of respondents, both within and outside sanctuary areas, perceive that hilsa production has increased as a result of establishing sanctuaries. This percentage is higher than that reported by Islam et al. (2016b), who also investigate perceptions toward hilsa shad sanctuaries. Based on individual interviews with fishermen who directly depend on fishing inside the sanctuaries for their livelihood, Islam et al. (2016b) report that around $75 \%$ of the respondents to their survey agree hilsa yields have increased to some extent in their fishing zone due to sanctuaries. Almost half of the respondents to our survey report catching larger sized hilsa, and $42 \%$ report that their income has increased as a result of better hilsa production. These findings are in agreement with Bladon et al. (2016b:21) who report that $40 \%$ of their respondents perceive an improvement in their livelihood status and income from fishing over the last 5-10 years. Nevertheless Bladon et al. (2016b:22) conclude that awareness of regulations is low in sanctuary areas, and that "sanctuary respondents were significantly less likely to report an increase in hilsa abundance, improvement in livelihood status, or positive impact of fishing bans on income and catch."

Our findings confirm that extreme poverty and lack of opportunities for alternative income-generating activities remain significant reasons for noncompliance with the hilsa ban period. Most respondents cite these as the main reasons for violating fishing bans. Although fishers are entitled to compensation for the loss of earnings due to fishing restrictions, they lack other entitlements and capabilities to improve their livelihood. For instance, they have limited access to formal credit, because they do not possess collateral such as assets and land. Due to their uncertain incomes, they have difficulties serving debt even on microcredit (Jentoft et al. 2010). A major shortcoming not addressed in the compensation scheme is that fishers during fishing bans are still required to repay interest on their debts, which may compel them to continue fishing. Paying weekly installments of microcredit is a burden for fishers because their income from fishing is the only way to repay their loan (Islam et al. 2017). Responses to our survey highlight that about $56 \%$ of fishers catch hilsa during ban periods. Reducing the loan burden is mentioned by $44 \%$ of respondents to be a major reason for not complying with fishing bans. Thus, under the current configuration of "carrot-and-stick" management in sanctuaries, continued poverty and debt lock-in remain endogenous selfreinforcing processes that reduce incentives for compliance despite compensation and recovery of hilsa stocks in return for compliance (Table 1; Fig. 2).

During the ban period, many fishers have no alternative source of income. Therefore, they often resort to the use of illegal gear and continue to fish illegally during fishing bans. Field observations illustrate this practice: "During the ban period, the fishers sell fish to transitory middlemen or mobile collectors, known as "jogandar" or "foria." A team of 4-5 labor fishers jointly rent a small boat and go fishing with monofilament gill nets, a low cost illegal gear locally known as "current jal" which is easy to handle, reducing the time of the operation" (A. B. M. Hossain, personal communication). It is noteworthy that almost a quarter of the respondents in our survey state "quick and easy earning" and "high return against low investment" as reasons for fishing during the ban period, suggesting that the benefits of noncompliance are perceived worth the risk of being caught and penalized for illegal fishing activity.

(ii) Perceptions of benefits in return for compliance Bladon et al. $(2016 b$ : 22) report that $95 \%$ of fishers do acknowledge the benefit of compensation for communities. They conclude that compensation for lost income through compliance 
with hilsa fishing bans has contributed to socioeconomic improvement amongst hilsa fishing households. Because causality cannot be inferred decisively from stakeholder perceptions, the extent to which compensation has actually incentivized compliance cannot be ascertained. In our survey, two-thirds of respondents, both in sanctuary and nonsanctuary areas, report receiving VGF support from the government in compensation for lost income during fishing bans. About $40 \%$ of respondents perceive that this incentive-based system contributes to effective implementation of the ban. The survey responses however suggest serious shortcomings in the allocation of support. About $40 \%$ of respondents perceive bias in the allocation process. Almost onequarter of respondents believe that the support is misallocated to nonfishers. Moreover, about $30 \%$ of respondents perceive that the assistance is not provided in timely manner and that they receive less rice than they are entitled to. The results also reveal large differences in perception of respondents between districts. Eighty percent of respondents in Chandpur suggest that rice is not received at the right time, and $65 \%$ suggest they receive less rice than their entitlement, compared with $17.5 \%$ and $15.5 \%$, respectively, in Bhola. This suggests large differences in the efficacy of government support provided across districts.

Opportunities for skills diversification outside of the fishing sector are, in this context, not only a priority in order to realize livelihood improvements, but also to incentivize voluntary compliance with fishing bans. Yet, few eligible fishers engage with support for alternative income-generating activities (AIGAs) provided by the government under its incentive scheme because, they claim, they do not have the required skills (Islam et al. 2016b). Illiteracy, an impediment to skills diversification, is widespread in fishing communities. We find low literacy rates among our cross-section of 1,200 hilsa fishing households, with $28 \%$ of respondents illiterate and $50 \%$ who have attended primary school only. Similarly, over one-third of fishers surveyed in Islam et al. 's (2016a) case study are illiterate. Education is considered a "luxury" poor fishers feel that they cannot afford because they cannot bear educational expenses. Their children need to work and help out in fishing to supplement the family income (Jentoft et al. 2010).

\section{Endogenous processes and livelihoods in the social-ecological system}

Our survey findings provide insights into endogenous selfreinforcing processes such as debts and low asset holdings and lack of social-ecological diversity, characterized by high dependency on income from fisheries with limited alternative income generation outside fisheries. We consider debt as a factor endogenous to the SES because indebtedness is possibly among the most severe constraints that hilsa fishers face in escaping the social-ecological trap, and inherently related to how power and patronage of actors within the SES perpetuate poverty and overexploitation in the Bangladesh hilsa fishery. Viewing indebtedness as endogenous to the fishery also illustrates the complex interdependencies between ecological and social processes that affect the provision and use of natural capital and persistence of poverty within the SES. Islam et al. (2017) explain how middlemen, who often are rich and powerful members of society, regulate fishers' behavior in the exploitation of fisheries resources. The hilsa fishery is a capital-demanding and laborintensive fishery. Because the majority of hilsa fishers are poor, they cannot afford access to fishing assets at their own expense. This paves the way for informal moneylenders to gain bargaining power over them. The centuries-old informal "dadon" system has been blamed for exploiting the fishers because it is a transaction built upon an often verbal lending contract that binds the fisher to the money lender ("dadondar"). As a key player and investor in the hilsa fishery, the fish trader ("arotdar") provides an advance loan ("dadon") to boat owners ("mohajan") for buying fishing gear and maintaining fishing boats on condition of the exclusive right to buy their catch (Pomeroy et al. 2016). The "mohajan," in turn, provides "dadon" to the fishers. The "arotdar" thus has control over a chain of suppliers bringing in regular catches and dominates the wholesale markets. Many "arotdars" have links to political parties and abuse their power by pushing their client fishers to continue fishing during ban periods. Islam et al. (2017) find that almost all of the fisher respondents in their case study are indebted through "dadon" to an "arotdar" or "mohajan." A video documentary produced by ECOFISH illustrates succinctly how income dependency on hilsa fishing and debts affect the livelihoods of fishing households in the SES: https://www. worldfishcenter.org/video/conserving-hilsa-and-building-livelihoodsbangladesh

We summarize the outcomes emerging from our survey in a comparative perspective, between sanctuary and nonsanctuary, as a household balance sheet accounting for income, assets, and savings vs. expenditure and debts. We separate the balance sheet into incomes and expenses directly related to fishing (i.e., fishing income, fishing assets, expenditure related to fishing, and debts to fish traders) and nonfishing-related income and expenses (Fig. 3). Similar to Bladon et al. (2016b) and Islam et al. (2016a), our study confirms that hilsa fishing households within sanctuary areas are more dependent on river fishing than households outside sanctuary areas. All 1,200 respondents in our study report that fishing is their main occupation and derive about $75 \%$ of their income from river fishery. Yearly household income from river fishery within sanctuary areas is similar to that found by Islam et al. (2016a), averaging at around BDT 90,000, but notably higher than that of households outside sanctuary areas (BDT 69,000). Hilsa fishing households within sanctuary areas also invest more in fishing-related assets such as boats and nets than similar households outside sanctuary areas. The average share of fishingrelated assets in the overall asset base of sanctuary households is $76 \%$ compared with $61 \%$ outside sanctuary areas. Bladon et al. (2016b) report that more experienced fishers are more likely to report an improvement in livelihood status, which indicates that fishing livelihoods are better now than in the past. Boat ownership and high income dependence on fishing correlate positively with reporting an increase in hilsa abundance and size, indicating that fishers who do invest more in fishing are more likely to perceive a positive change (Bladon et al. 2016b).

Bladon et al. (2016b) find that respondents who receive support for alternative income-generating activities have a significantly lower proportion of their income coming from fishing, but find no significant relationship between receiving support for alternative income generation and reporting an alternative livelihood despite the expectation that such support improves livelihood diversity. Only a small proportion (11\%) of respondents in that study receives compensation in the form of such activities. Alternative income generation has been suggested 
as having potential to generate income for repaying interest on debts during fishing bans. We find that higher dependence on fishing within sanctuaries is reflected in higher debts related to fishing. Moreover a significantly higher percentage of households within sanctuary areas are indebted to fish traders $(51 \%$ of households within sanctuaries vs. 20\% outside sanctuaries). Households within sanctuary areas on average have $27 \%$ of their debts outstanding with fish traders, whereas the percentage outside sanctuary areas is only $8 \%$. Respondents who are in debt are less likely to report an improvement in livelihood or increased income from fishing. Eighty-four percent of respondents to the survey by Bladon et al. (2016b) report being in debt, and a similar percentage sell their catch via middlemen, who are known to lock fishers in cycles of debt. Indebtedness has been linked to illegal fishing by numerous authors. Overall, in our survey $98 \%$ of respondents within sanctuary areas and $95 \%$ of respondents outside sanctuary areas report that they have debts. Critically, these household debts are almost equivalent to the annual income from fishing, implying a net zero balance without even accounting for other household expenses, including food. Food staples comprise the highest share in annual expenditure. Expenditures for staples are similar within and outside sanctuary areas. Expenditures for nonstaples, homestead, and fishing assets are nonetheless lower outside sanctuary areas, which may either reflect lower affordability due to lower overall household income, or lower prices of consumables and assets outside sanctuary areas. Households outside sanctuary areas appear to have slightly more homestead and livestock assets, but these are consistently valued lower than within sanctuary areas. Remoteness may be a factor of higher asset prices in sanctuary areas. Lower expenditure thus may compensate partially for lower income from fisheries outside sanctuary areas.

Fig. 3. Balance of fishing-related household income, assets, expenditure, and debts vs. nonfishing related ("Other") household income, assets, savings, expenditure, and debts; comparison between sanctuary and nonsanctuary fishing households

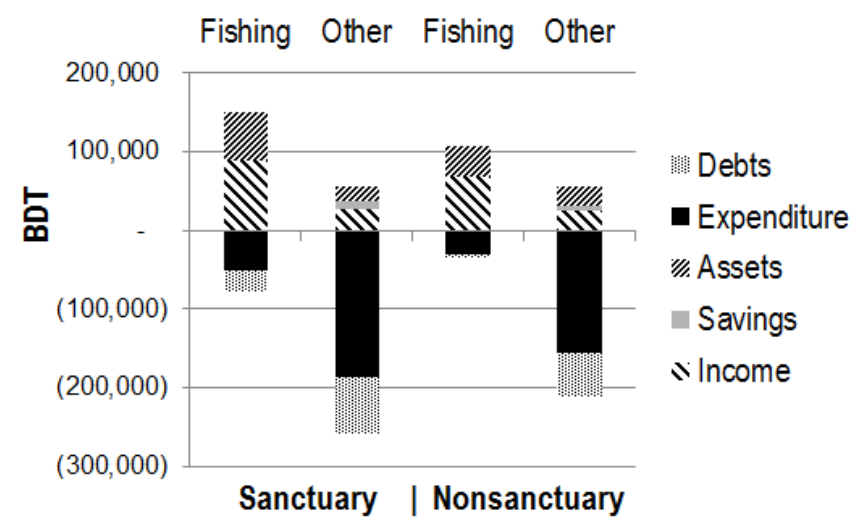

The overall outcome of our analysis suggests that the livelihood sustainability of hilsa fishing households is questionable both within sanctuary areas and outside sanctuary areas despite the incentives-based management approach currently in place. The balance of household income, assets, and savings vs. expenditure and debts is negative in both areas (Fig. 3). Annual household expenditure exceeds annual income and value of household assets. Porras et al. (2017:65) also suggest that hilsa fishers constantly operate at a financial loss. Although the overall income and asset base of hilsa fishing households outside sanctuary areas is lower than that within sanctuary areas, the reliance on hilsa fishing as the predominant livelihood is also lower outside sanctuary areas. Households outside sanctuary areas derive almost one-third of their income from sources other than fishery, compared with only $15 \%$ within sanctuary areas. Households outside sanctuary areas have more investments in assets outside fishery too (on average $39 \%$ of total household assets) than households within sanctuary areas (24\% of total assets). Notably almost a quarter of household investment outside sanctuary areas is in livestock, compared with less than $14 \%$ in households inside sanctuary areas.

\section{DISCUSSION}

Despite the formidable challenges, strong government commitment to rebuilding hilsa stocks and encouraging sustainable fishing practices by stick (enforcement of fishing regulations) and carrot (providing economic incentives from public funds) appears to have altered the SES trajectory toward higher hilsa production in Bangladesh. We have identified two critical junctures at which policy decisions influenced trap trajectories in the Meghna River linked SES: (1) declaration of open access to river fisheries, which is likely to have maintained if not reinforced social-ecological trap dynamics, and (2) declaration of hilsa fish sanctuaries, which altered trap dynamics in the SES toward recovery of hilsa stocks and biodiversity. Based on our insights, we have presented a conceptual model of how these critical junctures influence system trajectories by maintaining, reinforcing, or altering trap dynamics, resulting in different SES configurations (Fig. 2). We have identified which external factors and endogenous processes are the key drivers that maintain, reinforce, or alter trap dynamics influencing the SES. Table 1 summarizes these drivers and presents the main attributes that characterize the different system configurations both in terms of attitude and perceptions of fishers reliant on the SES, and their capacity and entitlements to improve and diversify their livelihoods.

We now briefly discuss social thresholds that, if crossed, potentially could help fishers to escape the social-ecological trap. First, greater participation of women in income generation could be pivotal to income diversification outside fisheries. The role of women in the household economy of hilsa fishers is important but largely hidden, both in terms of income generation and in terms of access to credit. Social and cultural norms restrict the participation of women in fishing and other income-generating activities, as well as their access to resources and control over decision making within the household. Our findings indicate that only $2 \%$ of women are directly involved in fishing. Nonetheless, around $69 \%$ of women are participating in different fishingrelated activities like preparing and repairing nets. Strikingly, $75 \%$ of women in fishing households surveyed both within and outside sanctuaries are involved in goat rearing, and goat rearing is the most frequently mentioned income-generating activity after river fishing. Income diversification outside the fishery sector could alleviate natural resource degradation, either directly through diminished use of natural resources, or indirectly because lower 
Table 2. Plausible future junctures and endogenous processes (social and ecological) that will influence trap dynamics, perception, and capacity-based attributes of each SES configuration, and its financial implications

\begin{tabular}{|c|c|c|c|c|c|}
\hline \multirow{2}{*}{$\begin{array}{l}\text { Plausible junctures } \\
\text { (future) }{ }^{\dagger}\end{array}$} & \multicolumn{2}{|c|}{ Endogenous processes and trap dynamics $^{\dagger}$} & \multicolumn{2}{|c|}{ Attributes of SES configuration } & \multirow[t]{2}{*}{ Financial implications } \\
\hline & Social & Ecological & Attitude and perception & Capacity and entitlement & \\
\hline $\begin{array}{l}\text { (3) Declaration of seasonal } \\
\text { blanket ban }\end{array}$ & $\begin{array}{l}\text { Widespread social } \\
\text { noncompliance may } \\
\text { reinforce }(+) \text { trap } \\
\text { dynamics }\end{array}$ & $\begin{array}{l}\text { Potential relapse of } \\
\text { overfishing and } \\
\text { environmental } \\
\text { degradation may } \\
\text { reinforce }(+) \text { trap } \\
\text { dynamics }\end{array}$ & $\begin{array}{l}\text { Simple but socially } \\
\text { unacceptable } \\
\text { enforcement may lead to } \\
\text { widespread } \\
\text { noncompliance }\end{array}$ & $\begin{array}{l}\text { Loss of income and } \\
\text { livelihood for up to } 3 \\
\text { million resource users; no } \\
\text { tenure entitlement, large } \\
\text { shortcomings in } \\
\text { compensation }\end{array}$ & $\begin{array}{l}\text { High increase in } \\
\text { transaction costs for } \\
\text { enforcement and } \\
\text { mitigating widespread } \\
\text { social noncompliance }\end{array}$ \\
\hline $\begin{array}{l}\text { (4) Institutionalizing } \\
\text { adaptive comanagement }\end{array}$ & $\begin{array}{l}\text { Collaboration and } \\
\text { collective action alter } \\
\text { trap dynamics (-) and } \\
\text { disrupt feedback loop }\end{array}$ & $\begin{array}{l}\text { Sustained fisheries } \\
\text { production and } \\
\text { environmental } \\
\text { health alter (-) trap } \\
\text { dynamics and } \\
\text { disrupt feedback } \\
\text { loop }\end{array}$ & $\begin{array}{l}\text { Strengthened resource } \\
\text { stewardship and } \\
\text { collective action; local } \\
\text { enforcement of } \\
\text { compliance with fishing } \\
\text { ban }\end{array}$ & $\begin{array}{l}\text { Entitlement to tenure; } \\
\text { increased capacity to } \\
\text { provide community } \\
\text { services or engage in } \\
\text { alternative income } \\
\text { generation, reduced } \\
\text { dependency on } \\
\text { compensation }\end{array}$ & $\begin{array}{l}\text { Reduced costs of } \\
\text { enforcement; increased } \\
\text { financial health of } \\
\text { fishery; reduced } \\
\text { poverty; increased } \\
\text { income from fishery; } \\
\text { sustainable finance } \\
\text { through trust fund }\end{array}$ \\
\hline
\end{tabular}

See Fig. 2

dependence on these resources can play a role in the emergence of successful common-pool resource management systems (Cinner et al. 2013, Stoop et al. 2016). Stoop et al. (2016) demonstrate with their case study in southern Benin that fishers are more likely to engage in activities outside the fishing sector in areas where natural resource degradation is more severe, and that "such diversification becomes more attractive as degradation worsens, lowering fishermen's reservation wage for outside employment" (Stoop et al. 2016: 686). Nevertheless, they conclude, the level of diversification away from the fisheries sector remains low, and lack of access to attractive options outside fisheries increases the risk of being locked into a povertyenvironment trap. They also find less diversified income among illiterate fishermen, and those who use productive, but highly damaging fishing gear. Our survey, in which almost all respondents perceive fishing to be their "only possible livelihood," points in a similar direction. We find that river fishing consistently provides higher income than employment outside fisheries, whereas income diversification is less within sanctuaries, where income from fisheries is higher than outside sanctuaries. This, in combination with the commonly held perception among fishers that hilsa catches have improved as a result of sanctuaries, could imply that under these conditions fishermen's reservation wage, the minimum wage that a fisher is willing to accept in order to substitute labor from fishing activities with employment outside the fishery (Stoop et al. 2016), will rise rather than decrease. As a consequence, any further diversification of income outside fisheries is likely to be driven by greater participation of women in income generation, which requires crossing the threshold of social and cultural norms that restrict participation and decision making by women in the household economy. Access to finance can be regarded another social threshold that needs to be overcome in order to stimulate entrepreneurship outside the fishery. Fishing households are often excluded from formal financial services due to collateral requirements, repayment schedules and high interest rates. Women in the fishing households typically are the main recipients of loans from rural microfinance institutions, however, they seldom have control over the loan. Our findings indicate that around $68 \%$ of women are involved in nongovernmental organization (NGO) microcredit groups. Although microcredit may increase participation of women in income generation, paying weekly installments of microcredit is widely perceived by fishers as a burden that they cannot afford, particularly during fishing bans when they have no income. Microfinance, therefore, may increase the risk of locking fishing households into a poverty-environment trap, driving fishers toward unsustainable exploitation practices such as fishing during ban periods to service the loan.

Now that we have unpacked the social-ecological trap in which small-scale fishing households reliant on this complex, highly natural resource-dependent system find themselves entrenched, we will build on these insights to discuss two potential junctures that, although not mutually exclusive, may reinforce and disrupt trap dynamics respectively: (3) imposition of a system-wide seasonal blanket ban on fishing in the SES and (4) improved governance through institutionalizing adaptive comanagement across the SES (Table 2; Fig. 2).

\section{Opportunities and limitations of two contrasting trajectories}

(i) A seasonal blanket ban on fishing in the SES

Bladon et al. (2016b) suggest a yearly recurring seasonal blanket ban on brood hilsa and jatka fishing in the whole Meghna River and estuarine ecosystem, reasoning that changing environmental conditions may have undermined the impacts of management in sanctuaries. The same authors argue that suitable habitat for hilsa is not concentrated in the sanctuary areas. A fishing ban throughout the river system should also reduce the chance of blockages in migratory routes undermining the impact of fishing bans (Bladon et al. 2016b). Declaration of such a blanket ban would mark another critical juncture in the trajectory of the SES. Although we do not dispute that a reconsideration of sanctuary boundaries may be needed, we argue that a blanket ban, contrary to its intended objective, is likely to reinforce rather than alter trap dynamics in the SES. Blanket implementation of fishing bans throughout the SES could be simpler from an enforcement 
perspective, but given the chronic lack of capacity for monitoring, control, and surveillance as well as the fragmentation of institutional control over access rights to fisheries, this does not seem a realistic option. Pomeroy et al. (2016) note that implementation of environment-related laws and regulations in Bangladesh is compromised by overlapping responsibilities between different agencies, lack of clear delegation of responsibilities, and lack of resources. Implementation of a blanket ban would have significant financial implications if coverage of the incentive scheme were to be expanded beyond the 287,000 hilsa fisher households estimated by DoF to have been directly affected by the declaration of sanctuaries (Mohammed and Wahab 2013). Bladon et al. (2016b) point out that the ban period coincides with the peak fishing season when, as Islam et al. (2016a) note, seasonal migrant fishers come from as far as North Bengal to participate in the hilsa fishery. If we assume that the 2.5 million people who engage parttime or indirectly in the hilsa fishery do so mainly during the peak fishing season and thus also would be affected by a blanket ban, considerable expansion of the compensation scheme might be required in this scenario. Moreover, if all fishing were prohibited during the ban, as currently is the case in sanctuaries, it might need to include nonhilsa fishers as suggested by Islam et al. (2016b). Overall, under this scenario, the transaction costs of mitigating widespread social noncompliance and avoiding a relapse of an undesirable configuration of the system may be just too high (Table 2).

\section{(ii) Institutionalizing adaptive comanagement across the social- ecological system}

Ratner et al. (2013) note that intentional transformation of governance institutions may be a necessary step toward the longer term goal of resilient livelihoods. This trajectory will require a shift away from the current top-down governance model toward a model of "adaptive governance," defined by Chaffin et al. (2014) as a "range of interactions between actors, networks, organizations, and institutions emerging in pursuit of a desired state for social-ecological systems" at the scale of the whole Meghna River and estuarine ecosystem. Providing small-scale fishers with the entitlements for local tenure and capabilities to make a living by responsible fishing or a choice of other livelihood options may be the most, if not only, viable trajectory toward disrupting trap dynamics in the Meghna River linked SES. Attributes of good governance such as inclusive decision making and strong mechanisms of accountability can be considered foundations to build these capabilities (Lebel et al. 2006). Islam et al. (2016a:213) claim that "Fishers believe that a comanagement approach involving fishers and government is the possible best management option for operating sanctuaries in a sustainable way." Respondents in their study often blame the application of a top-down management approach for the low levels of community engagement in sanctuary management. Support for government involvement in comanagement is strong where people want the state to establish property rights to exclude outsiders (Wilson et al. 2006). Empowering local fishermen to monitor and enforce compliance with the bans will also reduce enforcement costs incurred by the government (Islam et al. 2016a). There is, however, no obvious "one size fits all" model of comanagement for the entire coastal-marine ecosystem and stock of hilsa. Management must be shared by a variety of stakeholders, both hierarchically, as through multitier comanagement, and spatially, between different geographic subunits of the fishery (Pomeroy et al. 2016).

\section{SPECULATION}

\section{Reimagining large-scale open-water fisheries governance}

In this section, we reimagine how an innovative "hybrid" model of large-scale open-water fisheries governance in the Meghna River linked SES, predicated on responsive and accountable institutions for and by people who depend on the fishery and supported by sustainable finance, can move the SES into a more sustainable and robust trajectory (Fig. 2; Table 2). We engage in grounded speculation on how the incentive-based approach to management of the hilsa shad fishery could be recast to support this process. Islam et al. (2016a) point out that higher economic output of the fishery as a whole does not readily benefit all hilsa fishers because their wages do not change immediately due to higher harvests. Bladon et al. (2016a) argue that, when used together with conventional regulatory approaches, economic incentive mechanisms could play a significant role in incentivizing sustainable fishing practices in developing countries. As Lau (2013) writes, "incentives for behavioral changes to increase the provision of ecosystem services," commonly referred to as payment for ecosystem services (PES), reward resource users for improved practices or compensate them for the benefits forgone in compliance with regimes limiting their use of natural resources. Although the Bangladesh hilsa shad fishery does not fulfill all preconditions for an "ideal" PES a priori, Bladon et al. (2016a) argue that there are opportunities for "less-than-perfect PES schemes to benefit fisheries management and stakeholders." Their "verdict" on the fishery is that "recent political support for hilsa stock rebuilding indicates great potential for a national PES scheme to facilitate investment in capacity building for community-based monitoring and enforcement and the development of a more cooperative and integrated system of governance" (Bladon et al. 2016a:854).

According to Muradian et al. (2010), interest in PES in developing country policies is partly due to the expectation it can be a winwin mechanism for environmental protection and poverty alleviation. However, in reality, PES is designed to provide ecosystem services rather than reducing poverty. Other mechanisms, including direct payments to the poor, are more likely to reduce poverty than PES schemes. The compensation system currently in place for the hilsa fishery in Bangladesh does provide the foundation for a "true" PES but does not adequately fulfill Tacconi's (2012) definition of PES as "a transparent system for the additional provision of environmental services through conditional payments to voluntary providers." The best solution fulfilling both goals of poverty reduction among hilsa fishers and environmental objectives would be a cost-effective PES scheme that frees up resources for the most appropriate propoor program to complement the scheme. Implementation of PES can involve substantial changes to resource management practices and have significant implications for ecosystem service providers' livelihoods. Therefore, their right to choose which option they prefer should be taken into account (Tacconi 2012). DewhurstRichman et al. (2016) suggest financing options such as 
earmarking hilsa export tax revenues or levying fees along the hilsa supply chain, as well as financing through debt service liability schemes, climate funds, and dividends from deposits of seed capital in funds with registered banks.

\section{Recasting the safety net}

We adopt Tacconi's (2012) definition of PES in order to question whether or not the economic incentive mechanism currently implemented in the management of this fishery, framed as PES, can help alter trap dynamics in the SES. The in-kind provision of rice in compensation for compliance with fishing bans can conceptually be viewed as a safety net providing food assistance to the poorest fishing households, of which the total cost to the government of Bangladesh is in the order of USD \$14 million per year. Despite assertions that the conservation program presents "the most cost-effective and efficient way to manage natural resources" (Haldar and Ali 2014:2), it is essentially founded on a food-transfer program that incurs high transaction costs (del Ninno and Dorosh 2002). Bladon et al. (2016b) recommend a redesign of the rice and AIGA compensation schemes to better fit the needs of hilsa fishers and to increase their coverage in an equitable way. This can possibly be done by recasting the economic incentive scheme as it currently exists into a conditional cash transfer scheme that includes low-interest credit facilities to fishers, supported by a trust fund. The Conservation Finance Alliance (Spergel and Taïeb 2008) defines conservation trust funds (CTFs) as "private, legally independent grant-making institutions that provide sustainable financing for biodiversity conservation." Conservation trust funds have a demonstrated potential to advance economic incentive mechanisms such as PES because they can meet the need for recurrent long-term conservation funding. They can also help initiate and strengthen intersectoral collaboration and build institutional capacity at local and national levels, which is urgently needed for better governance of the hilsa shad resource.

From the perspective of efficiency and cost effectiveness, i.e., to make its implementation worthwhile, the payment for any given ecosystem service needs to cover the service provider's opportunity cost and minimize the cost of providing the ecosystem service payment from a societal perspective (Tacconi 2012). In our case, public funds are used to provide fishers with economic incentives in return for compliance. Opportunity costs associated with compliance could be lowered through conditional cash transfers or loans if better tailored to the timing of the fishing bans and sustainably financed through a hilsa CTF, which is currently under government consideration (Bladon et al. 2016b). We propose that the USD \$14 million worth of public funds now sunk yearly as in-kind compensation for lost income during ban periods through the hilsa conservation program could be invested in a cash-for-work program instead, to better target true hilsa fishers and avoid misallocation. Fishers often express their preference for a more holistic approach to development of their community through investments in roads and flood protection embankments, education, provision of low-interest credit facilities for all fishers, or assisting them to open savings accounts with minimal fees and requirements so that they can better withstand shocks and stresses related to natural disasters or declining catches (Mohammed and Wahab 2013). Public funds could potentially be better used to help finance such interventions and sustainably improve hilsa fishing livelihoods by paying fishers for providing services that improve their own community rather than perpetually continue to compensate them for a negative livelihood balance.

\section{CONCLUSION}

The present incentive-based approach to fisheries management in Bangladesh has led to a nominal improvement in well-being of fishing households who depend predominantly on the hilsa shad fishery. Despite the trajectory of recovery witnessed in hilsa shad stocks over the last decade, which was triggered by a policy decision in favor of incentive-based fisheries management that has realized tangible socioeconomic and ecological benefits through compensating hilsa fishing households for lost income resulting from seasonal fishing bans, the livelihood sustainability of hilsa fishing remains questionable. Debt-bonded relationships with informal credit providers who hold bargaining power over these fishing households perpetuate the social-ecological trap hilsa fishing households find themselves entrenched in. Fishers are entitled to compensation in return for compliance, but do not have any meaningful representation in resource management and decision making. Compensation of benefits forgone by complying with hilsa fishing ban periods and seasonal closure of all fisheries in sanctuary areas in this case only treats the symptoms of poverty and natural resource degradation but does not disrupt trap dynamics perpetuating the cycle of poverty, social exclusion, and political disempowerment. Sustainably financed interventions that adapt and transform household and community capacity, with choices and options to realize livelihood improvements outside of natural resource exploitation are urgently needed. Besides compensation for the loss of earnings during fishing ban periods, hilsa fishing households are in need of "hard" entitlements such as cash transfers and access to formal credit, but also "soft" entitlements such as equitable stakeholder representation with room for dissent and negotiation in order to break the trap dynamics.

The broadened concept of social-ecological traps proposed by Haider et al. (2018) that we adopted in this paper has helped to reimagine governance of the Meghna River linked SES. The sanctuaries set aside in this system with a view to safeguard the hilsa shad fishery offer as collateral clearly articulated ecosystem services that can form the foundation for wider local stewardship of the Meghna River and estuarine ecosystem. Adaptive comanagement involving communities and local fisher associations in monitoring and enforcement of compliance with fishing bans in this large SES may require massive mobilization of hilsa fishers backed by a secured tenure system predicated on responsive and accountable institutions for and by people who depend on the fishery. Such reimagined large-scale open-water fisheries governance ultimately encompassing the whole Meghna River and estuarine ecosystem, supported by sustainable finance, is to our knowledge the first open-water fisheries governance system of its kind being implemented at such large scale in a developing-country context. Meaningful participation of hilsa fishers and other stakeholders in this unique demonstration of contemporary large-scale open-water fisheries governance, supported by a trust fund that sustainably finances the transformation of household and community capacity to realize livelihood improvements outside of natural resource exploitation, may be the most, if not only, cost-effective solution for a sustainable future of this complex SES. 
Responses to this article can be read online at:

http://www.ecologyandsociety.org/issues/responses. php/9917

\section{Acknowledgments:}

This work was undertaken as part of the CGIAR Research Program on Fish Agri-Food Systems (FISH). The authors acknowledge the financial support provided by USAID through the Enhanced Coastal Fisheries in Bangladesh (ECOFISH) project, jointly led by the Department of Fisheries (DoF), Bangladesh and WorldFish. We are grateful to the two anonymous reviewers who have provided constructive feedback and comments on earlier versions, which enabled us to considerably improve the manuscript. We also acknowledge all respondents to our survey for sharing their perceptions and insights, and thank Mr. Md. Billal Hossain for providing the map of the survey area. The authors alone are responsible for the opinions expressed in this paper.

\section{LITERATURE CITED}

Amin, S. M. N., M. A. Rahman, G. C. Haldar, M. A. Mazid, and D. A. Milton. 2008. Catch per unit effort, exploitation level and production of hilsa shad in Bangladesh waters. Asian Fisheries Science 21(2):175-187.

Barbier, E. B. 2010. Poverty, development, and environment. Environment and Development Economics 15(6):635-660. http:// dx.doi.org/https://doi.org/10.1017/S1355770X1000032X

Barrett, C. B., and B. M. Swallow. 2006. Fractal poverty traps. World Development 34(1):1-15. http://dx.doi.org/10.1016/j. worlddev.2005.06.008

Bladon, A. J., K. M. Short, E. Y. Mohammed, and E. J. MilnerGulland. 2016a. Payments for ecosystem services in developing world fisheries. Fish and Fisheries 17(3): 839-859. http://dx.doi. org/https://doi.org/10.1111/faf.12095

Bladon, A. J., A. Syed, S. M. Hassan, A. T. Raihan, Md. N. Uddin, Md. L. Ali, S. Ali, Md. B. Hussein, E. Y. Mohammed, I. Porras, and P. Steele. 2016b. Finding evidence for the impact of incentivebased hilsa fishery management in Bangladesh: combining theory testing and remote sensing methods. International Institute for Environment and Development (IIED) Working Paper. IIED, London, UK. [online] URL: http://pubs.iied.org/16625IIED/

Boonstra, W. J., and F. W. de Boer, 2014. The historical dynamics of social-ecological traps. Ambio 43(3):260-274. http://dx.doi. org/10.1007/s13280-013-0419-1

Chaffin, B. C., H. Gosnell, and B. A. Cosens. 2014. A decade of adaptive governance scholarship: synthesis and future directions. Ecology and Society 19(3): 56. http://dx.doi.org/10.5751/ ES-06824-190356

Cinner, J. E. 2011. Social-ecological traps in reef fisheries. Global Environmental Change 21(3): 835-839. http://dx.doi.org/10.1016/ j.gloenvcha.2011.04.012

Cinner, J. E., M. A. MacNeil, X. Basurto, and S. Gelcich. 2013. Looking beyond the fisheries crisis: cumulative learning from small-scale fisheries through diagnostic approaches. Global
Environmental Change 23(6): 1359-1365. http://dx.doi.org/10.1016/ j.gloenvcha.2013.11.001

del Ninno, C., and P. A. Dorosh. 2002. In-kind transfers and household food consumption: implications for targeted food programs in Bangladesh. Food Consumption and Nutrition Division (FCND) Working Paper 134, International Food Policy Research Institute, Washington, D.C., USA. [online] URL: https://www.ifpri.org/publication/kind-transfers-and-householdfood-consumption-0

Dewhurst-Richman, N., E. Y. Mohammed, M. L. Ali, K. Hassan, M. A. Wahab, Z. F. Ahmed, M. M. Islam, A. Bladon, G. C. Haldar, C. S. Ahmed, M. K. Majumder, M. M. Hossain, A. Rahman, and B. Hussein. 2016. Balancing carrots and sticks: incentives for sustainable hilsa fishery management in Bangladesh. International Institute for Environment and Development (IIED) Working Paper. IIED, London, UK. [online] URL: http://pubs. iied.org/16619IIED/

Fisheries Resources Survey System (FRSS). 2017. Fisheries statistical report of Bangladesh. Volume 33, FRSS, Department of Fisheries, Bangladesh.

Haider, L. J., W. J. Boonstra, G. D. Peterson, and M. Schlüter. 2018. Traps and sustainable development in rural areas: a review. World Development 101:311-321. http://dx.doi.org/10.1016/j. worlddev.2017.05.038

Haldar, G. C., and L. Ali. 2014. The cost of compensation: transaction and administration costs of hilsa fish management in Bangladesh. International Institute for Environment and Development (IIED) Working Paper. IIED, London, UK. [online] URL: http://pubs.iied.org/16574IIED/

Hardin, G. 1968. The tragedy of the commons. Science 162:12431248. http://dx.doi.org/10.1126/science.162.3859.1243

Islam, M. M., N. Islam, A. R. Sunny, S. Jentoft, M .H. Ullah, and S. M. Sharifuzzaman. 2016a. Fishers' perceptions of the performance of hilsa shad (Tenualosa ilisha) sanctuaries in Bangladesh. Ocean and Coastal Management 130:309-316. http:// dx.doi.org/https://doi.org/10.1016/j.ocecoaman.2016.07.003

Islam, M. M., E. Y. Mohammed, and L. Ali. 2016b. Economic incentives for sustainable hilsa fishing in Bangladesh: an analysis of the legal and institutional framework. Marine Policy 68:8-22. http://dx.doi.org/https://doi.org/10.1016/j.marpol.2016.02.005

Islam, M. M., M. M. Shamsuzzaman, M. M. H. Mozumder, X. Xiangmin, Y. Ming, and M. A. S. Jewel. 2017. Exploitation and conservation of coastal and marine fisheries in Bangladesh: do the fishery laws matter? Marine Policy 76:143-151. http://dx.doi. org/10.1016/j.marpol.2016.11.026

Jentoft, S., P. Onyango, and M. M. Islam. 2010. Freedom and poverty in the fishery commons. International Journal of the Commons 4(1):345-366. http://dx.doi.org/10.18352/ijc.157

Lau, W. W. Y. 2013. Beyond carbon: conceptualizing payments for ecosystem services in blue forests on carbon and other marine and coastal ecosystem services. Ocean and Coastal Management 83:5-14. http://dx.doi.org/10.1016/j.ocecoaman.2012.03.011

Lebel, L., J. M. Anderies, B. Campbell, C. Folke, S. HatfieldDodds, T. P. Hughes, and J. Wilson. 2006. Governance and the 
capacity to manage resilience in regional social-ecological systems. Ecology and Society 11(1): 19. [online] URL: http://www. ecologyandsociety.org/vol11/iss1/art19/ http://dx.doi.org/10.5751/ ES-01606-110119

Mohammed, E.Y., L. Ali, S. Ali, B. Hussein, M.A. Wahab, and N. Sage. 2016. Hilsa's non-consumptive value in Bangladesh: estimating the non-consumptive value of the hilsa fishery in Bangladesh using the contingent valuation method. International Institute for Environment and Development (IIED) Working Paper. IIED, London, UK. [online] URL: http://pubs.iied. org/16626IIED/

Mohammed, E. Y., and M. A. Wahab. 2013. Direct economic incentives for sustainable fisheries management: the case of hilsa conservation in Bangladesh. International Institute for Environment and Development (IIED) Working Paper. IIED, London, UK. [online] URL: http://pubs.iied.org/16527IIED/

Mome, M. A. 2007. The potential of the artisanal hilsa fishery in Bangladesh: an economically efficient fisheries policy. Fisheries Training Programme, final project. United Nations University, Reykjavík, Iceland. [online] URL: http://www.unuftp.is/static/ fellows/document/masud07prf.pdf

Muradian, R., E. Corbera, U. Pascual, N. Kosoy, and P. May. 2010. Reconciling theory and practice: an alternative conceptual framework for understanding payments for ecosystem services. Ecological Economics 69(6):1202-1208. http://dx.doi.org/https:// doi.org/10.1016/j.ecolecon.2009.11.006

Nunan, F. 2015. Understanding poverty and the environment. Routledge, New York, New York, USA.

Pomeroy, R., P. Thompson, and C. Courtney. 2016. Marine tenure and small-scale fisheries: a summary of the Bangladesh experience and recommendations for the hilsa fishery. Bangladesh Marine Tenure Report. Tenure and Global Climate Change (TGCC) Program, USAID. [online] URL: https://www.land-links.org/wpcontent/uploads/2017/02/USAID Land Tenure TGGC Bangladesh_Lessons_Hilsa_Fishery.pdf

Porras, I., E. Y. Mohammed, L. Ali, M. S. Ali, and M. B. Hossain. 2017. Power, profits and payments for ecosystem services in Hilsa fisheries in Bangladesh: a value chain analysis. Marine Policy 84:60-68. http://dx.doi.org/10.1016/j.marpol.2017.06.031

Ratner, B. D., P. Cohen, B. Barman, K. Mam, J. Nagoli, and E. H. Allison. 2013. Governance of aquatic agricultural systems: analyzing representation, power, and accountability. Ecology and Society 18(4): 59. http://dx.doi.org/10.5751/ES-06043-180459

Reardon, T., and S. A. Vosti. 1995. Links between rural poverty and the environment in developing countries: asset categories and investment poverty. World Development 23(9):1495-1506. http:// dx.doi.org/10.1016/0305-750X(95)00061-G

Sahoo, A. K., Md. A. Wahab, M. Phillips, A. Rahman, A. Padiyar, V. Puvanendran, R. Bangera, B. Belton, D. K. De, D. K. Meena, B. K. Behera, A. P. Sharma, U. Bhaumik, B. P. Mohanty, S. R. Choudhury, and C. V. Mohan. 2016. Breeding and culture status of hilsa (Tenualosa ilisha Ham. 1822) in South Asia: a review. Reviews in Aquaculture: online early.
Sharma, A. P., N. C. Roy, and B. K. Barman. 2012. Hilsa: Its social, cultural, and religious importance. Pages 216-223 in Anonymous, editor. Hilsa: status of fishery and potential for aquaculture. Proceedings of the Regional Workshop held in Dhaka, 16-17 September 2012, The WorldFish, Bangladesh and South Asia Office, Dhaka, Bangladesh.

Spergel, B., and P. Taïeb. 2008. Rapid review of conservation trust funds. Working Group on Environmental Funds, Conservation Finance Alliance. [online] URL: https://www.cbd.int/financial/ trustfunds/g-rapidassess.pdf

Stoop, N., R. Houssa, and M. Verpoorten. 2016. To fish or not to fish? Resource degradation and income diversification in Benin. Environment and Development Economics 21(5):669-689. http://dx.doi.org/https://doi.org/10.1017/S1355770X16000012

Tacconi, L. 2012. Redefining payments for environmental services. Ecological Economics 73:29-36. http://dx.doi.org/10.1016/ j.ecolecon.2011.09.028

Thompson, P. M., P. Sultana, Md. N. Islam, Md. M. Kabir, Md. M. Hossain, and Md. S. Kabir. 1999. An assessment of comanagement arrangements developed by the community based fisheries management project in Bangladesh. Paper presented at the International Workshop on Fisheries Co-management, Penang, Malaysia, 23-28 August 1999. [online] URL: http://pubs. iclarm.net/Pubs/Way\%20Forward/21\%20Thompson.pdf

Wilson, D. C., M. Ahmed, S. V. Siar, and U. Kanagaratnam. 2006. Cross-scale linkages and adaptive management: fisheries comanagement in Asia. Marine Policy 30(5):523-533. http://dx.doi. org/10.1016/j.marpol.2005.07.001 